\title{
APPLICATION OF LARVITRAP AND OVITRAP TO CONTROL Aedes sp. IN DHF ENDEMIC AREAS
}

\author{
Arif Widyanto $^{1)}$, Aris Santjaka ${ }^{2)}$ \\ 1)2) Department of Environmental Health \\ Health Polytechnic of the Ministry of Health, Semarang, Indonesia
}

\begin{abstract}
Alternative mosquito vector control at this time that is cheap, practical and relatively safe to the environment is needed by developing countries such as Indonesia.

One of the methods of controlling Aedes sp without insecticides is the use of larvae traps (larvitrap). The working principle of larvitrap is that the eggs trapped in the tool The incidence rate (IR) of Dengue Hemorrhagic Fever per 100.000 population in Central Java in the last five years is as follows: 2011 amounted to 15,27 in 2012 amounted to 19,29 in 2013 amounted to 45,52 in 2014 amounted to 32,95 and years 2015 amounted to 34,87 . Since 2010 DHF has spread to all districts / cities in Central Java. Larvitrap and ovitrap are tools that can be used as traps for Aedes sp. Both of these tools can be used with additional attractants which can serve to attract the attention of Aedes sp. in order to lay eggs on the tool. Larvae that hatch from eggs in the larvitrap eventually cannot become adults and will die. Mosquito eggs trapped in the ovitrap can be destroyed so that they do not develop into adult mosquitoes. The research objective was to determine the effectiveness of using larvitrap and ovitrap as a control tool for Aedes sp (DHF vector).

The research method used is experimental research. The research location is in the Banyumas Regency area. Larvitrap made of plastic jars and pralon was painted black and modified using gauze on the top. Ovitrap from plastic cups was painted black and given an ovistrip. Larvitrap and ovitrap were placed in DHF endemic areas. After the larvitrap and ovitrap are taken, the number of trapped Aedes sp and the larvitrap / ovitrap index is calculated. Furthermore, analyzed the effectiveness of using larvitrap and ovitrap as a means of controlling mosquitoes Aedes sp.

The results showed that the larvitrap index in the larvitrap installation in Pandak Village was $60 \%$, while in Mersi Village it was 56,7\%. The ovitrap index in the ovitrap installation in Pandak Village was $36,7 \%$, while in Mersi Village it was $33,3 \%$. The number of larvae trapped in the larvitrap installation in Pandak Village were 832 larvae, while in Mersi Village there were 985 larvae. The number of eggs trapped in the ovitrap installation in Pandak Village were 518 eggs, while in Mersi Village there were 811 eggs.

The conclusion of this research is that larvitrap is more effective to control Aedes sp than ovitrap. The community is advised to use larvitrap as a tool to control the Aedes sp (DHF vector.
\end{abstract}

Keywords: larvitrap, ovitrap, Aedes sp

\section{Introduction}

DHF is caused by dengue fever virus with types DEN-1, DEN-2, DEN-3 and DEN-4. The virus is included in Arthropod borne viruses (arboviruses) and is included in the category or family of Flaviviridae. Dengue virus can be transmitted through the bite of Aedes mosquitoes, especially Aedes aegypti. (Dantji T. Sembel, 2009, p. 60).

(larvitrap) will become larvae, but these larvae cannot grow into adults because the larvae will continue to be trapped in water so that they do not have the opportunity to become adults. Larvitrap can be made by modifying various materials found in the community, for example plastic foam, bamboo pieces or used cans.
Ovitrap is a tool to detect the presence of Aedes sp mosquitoes if the mosquito density is low and the larvae survey shows unproductive results $($ Breteu Index $<5)$. Apart from being a survey tool, ovitrap can also function as a dengue vector control tool. The standard ovitrap is a wide-mouth glass tube painted black on the outside. The glass tube is equipped with a wooden stick or filter paper as a place for the Aedes sp. The tubes are filled with water about a third to half, and placed in locations that are suspected to be mosquito habitat, usually inside and outside the house.

Larvitrap and ovitrap treated with attractant can attract the attention of Aedes sp to lay eggs on 
these larvae or ovitraps so that mosquitoes are expected not to lay eggs elsewhere. The use of attractant has been shown to attract mosquitoes to lay their eggs on the attractant. Straw soaking water is one of the attractant that has been proven to be effective in attracting mosquitoes to lay eggs (Arif Widyanto, 2015).

Dengue Hemorrhagic Fever (DHF) is a serious problem in Central Java Province. It is proven that in 35 districts / cities have contracted DHF. In Banyumas Regency, in the last five years, the number of dengue cases has fluctuated. In 2016 there were 990 cases of DHF, in 2017 there were 68 cases, in 2018 there were 55 cases, in 2019 there were 202 cases, and in 2020 there were 209 cases (Banyumas District Health Office, 2020).

On the basis of this description, researcher are encouraged to carry out research on the effectiveness of larvitrap and ovitrap as a control tool for Aedes sp. This reserach aims to calculate the index larvitrap, index ovitrap, the number of larvae trapped in the larvitrap and the number of eggs trapped on the ovitrap.

\section{Material and Method}

The research method used is experimental research. The research was conducted in DHF endemic areas in Banyumas Regency, namely in Mersi Village, East Purwokerto District and in Pandak Village, Baturraden District. Sampling of respondents as the research site was carried out by purposive sampling, namely in the RT area which had the highest cluster cases of dengue fever.

Larvitrap is made from a modified plastic jar and plastic pralon that is painted black and given gauze as a trap so that the larvae do not develop into adult mosquitoes. Ovitrap is made from plastic cups that are painted black on the outside. Filter paper is placed in a circle on the inner wall of the glass to attach the mosquito eggs. At the time of installation, larvitrap and ovitrap were filled with attractant from straw soaked water. Larvitrap and ovitrap are placed side by side at a distance of $50 \mathrm{~cm}$ in the house (especially in dark and humid places where mosquitoes hide, such as under tables, chairs, beds, and other potential places). Larvitrap and ovitrap were observed / examined once every three days for one week.

\section{Result and Discussion}

a. Environment Condition

Measurement of physical environmental conditions at the research location includes temperature and humidity. The results of measuring the temperature and humidity of the average air at the respondent's house are as follows:
Table 1. Temperature and humidity conditions

\begin{tabular}{|l|c|c|}
\hline \multicolumn{1}{|c|}{ Village } & Temperature & Humidity \\
\hline Pandak Village & $27-28^{\circ} \mathrm{C}$ & $71-76 \%$ \\
\hline Mersi Village & $30-33^{\circ} \mathrm{C}$ & $56-65 \%$ \\
\hline
\end{tabular}

The results of temperature measurement at the respondent's house in Pandak Village were $27-28^{\circ} \mathrm{C}$ and in Mersi Village it was $30-33^{\circ} \mathrm{C}$. The rate at which mosquitoes develop depends on the speed of the metabolic process which is partly influenced by temperature. In the homes of the respondents studied, the air temperature tends to be high and is less than optimal for mosquito growth. Mosquito growth will stop completely if the temperature is less than $100 \mathrm{C}$ and over $400 \mathrm{C}$. The optimum average temperature for the development of mosquitoes is 250-270C. (DIT.JEN.PP \& PL, 2007).

Air temperature affects the development of the Aedes sp. Mosquito. At temperatures of more than 350C, mosquitoes also experience changes in the sense of slower physiological processes. This is due to protein denaturation in the mosquito's body and the possibility of disturbed balance in the metabolic process and the emergence of toxic metabolic waste in the body so that it will reduce mosquito activity. (Abdul Syukur, 2012).

The role of temperature is widely related to the respiratory system of mosquitoes. The respiratory system of mosquitoes uses the trachea system, which is a breathing apparatus owned by mosquitoes which leads to a spiracle, which is a small hole with a diameter of less than $1 \mathrm{~mm}$ located in the outer frame (exoskeleton) located in pairs on each segment of the body, this spiracle has a valve that is controlled by a muscle so that it opens and shut down regularly. This spiracle will close when the mosquito is resting and open for a moment if needed, but if the mosquito flies, the spiracle is open. The closure of the spiracle at rest so that mosquitoes do not lack a lot of fluids, because mosquitoes do not have a regulator to retain moisture. (Aris Santjaka, 2013, p. 58).

In addition to the air temperature, the respondents' homes were also measured in terms of humidity. Air humidity is the amount of water vapor in the air which is usually expressed in percent (\%). If there is a large lack of water in the air, then this air has a large evaporation power. The respiratory system in mosquitoes is using spiracle. The existence of an open spiracle without any regulatory mechanism, at low humidity will cause water evaporation from the mosquito's body which can cause the mosquito's body fluids to dry. One of the enemies of mosquitoes is evaporation. At a humidity of less than $60 \%$, the mosquito's lifespan will be short so that it is not 
sufficient for the parasite growth cycle in the mosquito's body. (Ditjend PPM \& PL, 2004, p. 9).

Humidity measurements were carried out at the respondent's house near the ovitrap installation. The average humidity measurement result from the respondent's house in Pandak Village is $71-76 \%$ and in Mersi Village is $56-65 \%$. The humidity in the research location in Pandak Village is optimal for mosquito breeding, while in Mersi Village it is not sufficient for mosquito breeding. Mosquitoes generally like humidity above $60 \%$, because at humidity $<60 \%$ the mosquito lifespan will be shorter, so the mosquito population is not large. At high humidity, the mosquitoes become more active and bite more often so that it will speed up the mosquito breeding process.

b. Result Observation of Ovitrap and Larvitrap

Locations for the installation of larvitrap and ovitrap in Pandak Village and Mersi Village were each carried out in 30 respondents houses. The results of larvitrap and ovitrap observations are as follows:

Tabel 2. Result Observation of Ovitrap and Larvitrap

\begin{tabular}{|l|c|c|}
\hline \multicolumn{1}{|c|}{ Observed Items } & $\begin{array}{l}\text { Pandak } \\
\text { Village }\end{array}$ & $\begin{array}{l}\text { Mersi } \\
\text { Village }\end{array}$ \\
\hline $\begin{array}{l}\text { The amount of } \\
\text { larvitraps installed } \\
\text { larvitraps }\end{array}$ & $\begin{array}{l}\text { larvitraps } \\
(60 \%)\end{array}$ & $\begin{array}{l}17 / 30 \\
\text { Larvitrap index }\end{array}$ \\
\hline $\begin{array}{l}\text { Number of trapped } \\
\text { larvae }\end{array}$ & 832 larvae & 985 larvae \\
\hline $\begin{array}{l}\text { The amount of } \\
\text { ovitraps installed }\end{array}$ & 30 & 30 \\
& $11 / 30$ & $10 / 30$ \\
ovitraps & $33,3 \%$ \\
\hline $\begin{array}{l}\text { Ovitrap Index } \\
\text { eggs }\end{array}$ & 518 eggs & 811 eggs \\
\hline
\end{tabular}

\section{References}

Arif Widyanto, dkk, 2015, Pengaruh Berbagai Jenis Atraktan Dalam Ovitrap Terhadap Jumlah Telur Nyamuk Aedes sp, Purwokerto:
Based on table 2 it can be seen that the larvitrap index in Pandak Village was as much as $60 \%$, while the ovitrap index was $36.7 \%$. This shows that the use of larvitrap as a means of controlling the Aedes sp in Pandak Village is more effective than using ovitrap. Thus, it can be interpreted that the Aedes sp in Pandak Village prefers to lay eggs in the larvitrap model that the researchers made compared to the ovitrap. The community in Pandak Village can take advantage of the research results, namely by using larvitrap as a means of controlling the Aedes sp.

Based on table 2, it can also be seen that the larvitrap index in Mersi Village was 56,7\%, while the ovitrap index was $33.3 \%$. This shows that the use of larvitrap as a means of controlling Aedes sp in Mersi Village is more effective than using ovitrap. Thus, it can be interpreted that the Aedes sp in Mersi Village prefers to lay eggs in the larvitrap model that the researchers made compared to the ovitrap. People in Mersi Village can take advantage of the research results, namely by using larvitrap as a means of controlling Aedes sp.

\section{Conclusions and Suggestions}

Based on the results of research and discussion, it can be concluded that:

a. Larvitrap index in larvitrap installation in Pandak Village was $60 \%$, while in Mersi Village it was $56,7 \%$.

b. Ovitrap index on ovitrap placement in Pandak Village was 36,7\%, while in Mersi Village it was $33,3 \%$.

c. The number of larvae trapped in the larvitrap installation in Pandak Village were 832 larvae, while in Mersi Village there were 985 larvae.

d. The number of eggs trapped during the ovitrap installation in Pandak Village were 518 eggs, while in Mersi Village there were 811 eggs.

e. Larvitrap can be declared more effective as a control device for Aedes sp compared to ovitrap.

It is suggested to the public to use larvitrap as a tool to control the Aedes sp (DHF vector) as an alternative method of controlling the DHF vector. Similar studies can be carried out in the future using various larvitrap models. 
Astuti, Puji Endang. 2011. Efektivitas Alat Perangkap (Trapping) Nyamuk Vektor Demam Berdarah Dengue dengan Fermentasi Gula. Jurnal Kesehatan Masyarakat Vo. 3 No.1. diakses di http://ejournal.litbang.depkes.go.id/index.php /aspirator/article/view/2957.

Cecep Dani Sucipto, 2011, Vektor Penyakit Tropis, Yogyakarta : Gosyen Publishing

Dantji T. Sembel, 2009, Entomologi Kedokteran, Yogyakarta : CV ANDI OFFSET

Departemen Kesehatan R.I. Direktorat Jenderal Pengendalian Penyakit dan Penyehatan Lingkungan, 2007, Ekologi dan Aspek Perilaku Vektor, Jakarta: DIR.JEN. PP \& PL

), 2007, Survai Entomologi Demam Berdarah Dengue, Jakarta: DIR.JEN. PP \& PL

Dinas Kesehatan Kabupaten Banyumas, 2020, Laporan Kasus Demam Berdarah Dengue, Purwokerto: Dinas Kesehatan Kabupaten Banyumas.

Dirjen PPM dan PLP, 1992, Petunjuk Teknis Pemberantasan Nyamuk Penular Penyakit Demam Berdarah Dengue, Jakarta: Depkes RI

Handrawan Nadesul, 2007, Cara mudah Mengalahkan Demam Berdarah. Jakarta: Kompas, Mei 2007.

Notoatmodjo, Soekidjo, 2002, Metodologi Penelitian Kesehatan, Ed. Revisi, Jakarta: Rineka Cipta.

Polson KA, Curtis C, Seng CM, Olson JG, Chanta N, Rawlins SC. The use of Ovitrap Baited with
Hay Fusion as a Surveilance Tool for Aedes aegypti Mosquitoes Cambodia Dengue Bulletin 2002. Vol. 26: 178-184.

Salim, Milana dan Tri Baskoro T.S. 2015. Uji Efektifitas padaLethal Ovitrap Terhadap Jumlah Nyamuk dan Daya Tetas Telur Nyamuk Aedes Aegypti. Buletin Penelitian Kesehatan. Vol. 43, No. 3. http://www.ejournal.litbang.depkes.go.id/inde x.php/BPK/article/view/4342.

Sayono, 2008, Pengaruh Modifikasi Ovitrap Dengan Kassa Nylon Penutup Permukaan Air dan Berbagai Jenis Antraktan Terhadap Jumlah Nyamuk Aedes Yang Terperangkap, Semarang at http://jurnal.unimus.ac.id.

Sayono, dkk. (2010). Dampak Penggunaan Perangkap Dari Kaleng Bekas Terhadap Penurunan Populasi Nyamuk Aedes sp (Studi Awal Potensi Pengendalian Vektor Demam Berdarah Dengue Berbasis Komunitas), at http://jurnal.unimus.ac.id.

Service MW, 1996, Medical Entomology for Students, London: Chapman \& Hall, p 54-78, https://core.ac.uk/download/ files/ $379 / 11718326$.

Soegeng Soegijanto, 2008, Demam Berdarah Dengue Edisi 2, Surabaya: Airlangga University Press.

Weinzierl, R., et al., 2005, Insect Attractants and Traps. University of Florida, at http://www.faunajournal.com/vol1Issue3/Issu e_mar_2014/3.1. 